\title{
The Effects of Suckling and Artificially Providing Colostrum (Varying Amount) on The Passive Immunity of Newborn Calves
}

\author{
Mehmet DÜZER'1, Abuzer ACAR ${ }^{*}$ \\ 1 Afyon Kocatepe University, Faculty of Veterinary Medicine, Department of Internal Diseases, 03200, Afyonkarahisar, Turkey
}

\begin{abstract}
Calves need to be healthy for herd progression in sustainable cattle management. Adequately feeding the calves with good quality colostrum is reportedly one of the most important factors affecting their health, growth, immune system, and vitality. Here, we randomly selected new-born calves, purchased from Afyon Ballipinar Simental Company, regardless of their sex and divided them equally into separate groups. They were categorized ensuring that the parity of cows in the groups was balanced. We included 27 calves (15 females and 12 males) in this study. The animals were categorized as follows: Group 1: calves that consumed the colostrum directly from the udder; Group 2: Calves that consumed the colostrum (approximately $5 \%$ of their birth weight) with a feeding bottle; and Group 3: Calves that consumed the colostrum (nearly 8\% of their birth weight) through the feeding bottle. It is important to immediately administer the colostrum to the calves after their birth while maintaining hygiene. The feeding method or amount can be selected after considering the infrastructure and facilities of the company. Controlling the immunoglobin levels with a refractometer may lead to inconclusive results. Considering this, the most accurate method to identify the immunoglobulins is ELISA. Therefore, our results revealed that the calf-deaths associated with colostrum failure could be minimized by producing refractometers suitable for practical use or ready-made diagnostic kits that provide results that are as reliable as ELISA.
\end{abstract}

Keywords: Colostrum, Refractometer, Immunoglobulin, ELISA, Calf

\section{$* * *$ \\ Yeni Doğan Buzağıların Kolostrumu Emerek ve Suni Yollarla Değişik Oranlarda Verilmesinin Pasif İmmunite Üzerindeki Etkilerinin Karşılaştırılması}

\section{ÖZ}

Sürdürülebilir nitelikteki sığır işletmelerinde sürü devamlılığı bakımından buzağıların sağlıklı olması çok önemlidir. Buzağıların çok iyi nitelikte kolostrumla yeterli miktarda beslenebilmesi; buzağının sağllğı, gelişimi, immun sistemi ve yaşama gücü üzerindeki en önemli faktör olarak gösterilmektedir. Sunulan bu çalışmada hayvan materyalini yeni doğmuş simental 1rkı buzağılar oluşturmaktadır. Hayvanlar, Afyon Ballıpınar Simental İşletmesinin damızlık hayvanlarından doğan buzağılardan cinsiyet ayrımı yapılmaksızın rastgele seçildi ve gruplara dengeli olarak dağıtıldı. Gruplardaki annelerin laktasyon sayısının dengeli olmasına dikkat edildi. Çalışmada 15 dişi 12 erkek olmak üzere toplam 27 buzağ1 kullanıldı. Grup 1: Annesini direkt olarak memesinden emen buzağılar, Grup 2: Doğum ağırlığının \%5'i kadar kolostrumu biberon ile emen buzağılar, Grup 3: Doğum ağırlığının \%8'i kadar kolostrumu biberon ile emen buzağılar olmak üzere 3 gruba ayrıldı. Doğum sonrası en hijjenik ve çabuk şekilde buzağının kolostrum alması sağlanmalıdır. Buradaki yöntem ya da miktar işletmenin alt yapısı ve olanaklarına göre seçilebilir. Refraktometre ile lg seviyesinin kontrolü yanıltıcı sonuçlar verebilir. Bu nedenle en doğru yol ELISA ile immunglobulin tayinidir. Bu nedenle, araştırmamızdan elde edilen sonuçlar 1şı̆̆ında, gelişen teknoloji ile birlikte daha hassas ölçüm yapabilen, pratik kullanıma uygun refraktometrelerin ya da ELISA kadar güvenilir sonuçlar veren hazır tanı kitlerinin üretilmesi ile kolostrum yetmezliğine bağlı buzağı kayıplarının en aza indirilebileceği sonucuna varild1.

Anahtar Kelimeler: Kolostrum, Refraktometre, Immunglobulin, ELISA, Buzağ1

To cite this article: Düzer M. Acar A. The Effects of Suckling and Artificially Providing Colostrum (Varying Amount) on The Passive Immunity of Newborn Calves. Kocatepe Vet J. (2020) 13(1):92-97. 


\section{INTRODUCTION}

Calf health is imperative for herd continuity in sustainable cattle farms. Adequately feeding the calves with high quality colostrum is reportedly considered to be one of the most important factors affecting their health, growth, immune system, and vitality. Global calf mortality rate is $20 \%$, even in developed countries in terms of animal husbandry. This could be primarily attributed to insufficient and incorrect feeding techniques. However, previous research shows that the mortality rate in calves can be reduced to $3-5 \%$ with good care-feeding and colostrum management. Accordingly, colostrum s regarded as a unique nutrient in terms of reducing health problems and minimizing calf losses (Özen 1999).

Colostrum, is necessary to ensure the survival of newborn calves, it is extremely nutritious and is rich in energy, vitamins, minerals, and immunoglobulins (Ig) that are essential for the calves' growth and development. The ratio of dry matter in milk $(12 \%)$ is considerably lower than that in colostrum $(22 \%)$, and this difference is largely due to the presence of immunoglobulins in the latter. The immunoglobulins neutralize the pathogenic bacteria that cause diarrhea (Selk 2003). Additionally, colostrum is a laxative that stimulates the normal function of the digestive system (Wattiaux 2014). Furthermore, it is an excellent source of energy as it is rich in animal fat and carbohydrates and is responsible for regulating the body temperature. It also contains trypsin inhibitors and protein structures that accelerate the absorption of Ig and prevents their destruction in the intestine (Selk 2003, Quigley et al. 2009). Although the colostrum is generally thought to be produced between the $6^{\text {th }}-10^{\text {th }}$ milking after birth, the true colostrum is obtained in the first milking. It is called "transitional milk" since the milk structure and consistency appears to transform from colostrum to milk from the second milking to the eighth (Wattiaux 2014). Colostrum becomes milk in transit for approximately $48 \mathrm{~h}$, and normal milk in 72 hours (Şenturk 2012).

A healthy immune system is necessary to resist diseases; however, this system cannot provide complete protection to the new-born calves against diseases. Feeding colostrum to new-born calves is imperative since the immunoglobulins that are absorbed via the small intestine create a passive immunity against infections (Korhonen et al. 2000, Hamilton and Giesen 2003, Morter 2003). A serum Ig concentration of $\geq 10 \mathrm{mg} / \mathrm{mL}$ indicated the presence of adequate passive immunity (Waterman 1998). This can be ensured by administering the calves with $100 \mathrm{~g}$ of $\operatorname{IgG}$ in the first 12 hours. Calves should not allowed to suckle immediately after birth (Hurley and McCoy 2003), since it may result in high rates of passive transfer insufficiency (Weaver et al 2000).
Reportedly, the ideal method to administer colostrum is using a (measured) bottle in a controlled manner. In addition, we can use this method to calculate the amount of colostrum consumed by the calf. Colostrum can be administered to calves with probe application; however, this method may lower the serum IgG levels considering the fact that probeadministered-colostrum first enters the rumen and is absorbed in the abomasum and subsequently the intestines. However, it takes 2-4 hours to transfer the colostrum from the rumen, resulting in lower levels of Ig in the intestines (Quigley and Drewry 1998).

This study aimed to compare the immunoglobulin levels of calves that drank the colostrum directly from the mother in their first two meals, those drinking 5\% of the birth weight through a bottle, and those drinking $8 \%$ of the birth weight in a bottle. Additionally, we aimed to identify the most efficient and beneficial method for breeders, to guide them in revising or changing their current methods, and to be beneficial in our efforts to cause a nation-wide reduction in calf mortality.

\section{MATERIALS and METHODS}

We used 27 new-born Simental breed calves (15 females and 12 males). We ensured that the lactation number of the mothers in the groups was balanced and the mothers in the mean 3rd lactation were included in the study. The breeding cows underwent a standard dry period feeding and vaccination program. The new-born calves were dried by either being licked their mothers or using a clean towel. We examined their abdomen and recorded their birth weights. The colostrum brix refractometer values of the calves' mothers were recorded. Concurrently, we stored some of these colostrum samples at $-20^{\circ} \mathrm{C}$ for ELISA analysis. The official ear tags of the calves were attached on the day they were born. The calves were housed in the same maternity and calf paddock and were fed with calf feed in the form of 2-day-old mixture of water and pellets.

\section{Experimental Design}

Three different experimental groups were created by randomly selecting the calves. Group I $(\mathrm{n}=6)$ : Calves were encouraged drink from the udder and were helped by the staff to suckle after being licked and dried by their mother. The calves started suckling approximately 30 minutes after birth and were permitted to suckle and stop voluntarily. After 10 hours, the calves that had stopped sucking voluntarily were taken to a separate calf compartment and was placed closer to their mother's udder for a second meal. The calf continued to suckle to satiation. In the 3rd and subsequent meals, 2.51 milk was given to the calf with a nursing bottle, which changed to milk replacement food after the 6th meal. 
Group II ( $\mathrm{n}=10)$ : We measured the calves' birth weight and fed them their mother's milk by weighing equal to $5 \%$ of their birth weights in feeding bottles. The calves started suckling nearly 30 minutes after birth. Subsequently, they were separated from their mothers and taken to a different room. Approximately $10 \mathrm{~h}$ later, we collected the mother's milk equal to $5 \%$ of the calves' birth weight and fed the calves with a feeding bottle for their second meal. In the $3^{\text {rd }}$ and subsequent meals, 2.51 milk was given to the calf with a nursing bottle, which was changed to a milk replacement feed after the 6th meal.

Group III ( $\mathrm{n}=11)$ : We fed the calves in this group with feeding bottles by weighing out their mother's milk equal to $8 \%$ of the calf's birth weight. The calves started suckling 30 minutes after birth. The calves were then placed in a separate room. Approximately $10 \mathrm{~h}$ later we fed the calves with an identical quantity of their mothers' milk with a feeding bottle for their second meal. In the 3rd and subsequent meals, 2.51 milk was given to the calf with a nursing bottle, which was changed to milk replacement food after the 6th meal.

\section{Samples and Measurements}

Blood IgG levels were determined by collecting the serum, obtained by centrifuging the blood from V. jugularis (1500 cycles, 10 minutes) $24 \mathrm{~h}$ after birth and on the $7^{\text {th }}$ day after birth when the calves no longer suckle or drink from the feeding bottle. The blood was stored at $-20^{\circ} \mathrm{C}$ for ELISA analysis.

We recorded the colostrum brix refractometer values of the calves' mothers, while concurrently freezing these samples at $-20{ }^{\circ} \mathrm{C}$ for ELISA analysis. Frozen blood serum and colostrum were delivered to the laboratory in the cold chain after completing the sampling. The samples were then analyzed with a Biotek elx800 device using the ELISA method and the Biox branded IgG kit according to the manufacturer's protocol. The calves' body weights were measured and recorded when they were 30 days of age.

\section{Statistical Analyses}

Descriptive statistics (Frequency, Percentage, Arithmetic Mean, and Standard Deviation) were used in the study, and the presence of inter-group differences was tested with Single Factor Variance Analysis. The data obtained in the study were analyzed with SPSS 18.01 for Windows package program and studied with a significance level of 0.05 . Pearson correlation analysis was performed to determine whether there was a relationship between refractometer measurement results of colostrum samples and immunoglobulin levels in the colostrum determined by ELISA.

\section{RESULTS}

Birth weights were recorded for all experimental groups. Accordingly, the calf with the lightest and the heaviest calves at birth weighed $36 \mathrm{~kg}$ and $54 \mathrm{~kg}$, respectively. The lowest and highest values with regard to the colostrum IgG levels were 30.37 $\mathrm{mg} / \mathrm{mL}$ and $85.15 \mathrm{mg} / \mathrm{mL}$, respectively. The lowest value for the calves' blood serum immunoglobulin levels was $1.48 \mathrm{mg} / \mathrm{mL}$ and the highest was 8.77 $\mathrm{mg} / \mathrm{mL}$. At 1 day of age, the lowest blood serum $\mathrm{IgG}$ level was $30.58 \mathrm{mg} / \mathrm{mL}$ and the highest was 86.85 $\mathrm{mg} / \mathrm{mL}$. The lowest recorded $\mathrm{IgG}$ level in the blood serum was $27.66 \mathrm{mg} / \mathrm{mL}$ and the highest value was $76.18 \mathrm{mg} / \mathrm{mL}$ on the 7 th day. The calves were weighed on the 7th day, and the lowest and highest body weights were $38 \mathrm{~kg}$ and $58 \mathrm{~kg}$, respectively. On their $30^{\text {th }}$ day, the lowest body weight was $39 \mathrm{~kg}$ and the highest was $63 \mathrm{~kg}$; furthermore, we measured the daily body weight gains of the calves at that age, with the lowest being $-0.200 \mathrm{~kg}$ and highest $0.500 \mathrm{~kg}$ (Table 1, 2).

The results of the refractometer measurements of the colostrum samples did not demonstrate any significant correlation with that of the immunoglobulin levels in the colostrum determined by ELISA (Table 3).

Table 1. The descriptive statistics of weight and colostrum measurements in calves

\begin{tabular}{lccccc}
\hline Variables & Unit & Minimum & Maximum & Mean & $\begin{array}{c}\text { Standard } \\
\text { deviation }\end{array}$ \\
\hline Birth weight & $\mathrm{Kg}$ & 36.00 & 54.00 & 43.59 & 5.44 \\
Colostrum Ig levels & $\mathrm{mg} / \mathrm{ml}$ & 30.37 & 85.15 & 64.56 & 13.39 \\
Calf postpartum Ig levels & $\mathrm{mg} / \mathrm{ml}$ & 1.48 & 8.77 & 2.25 & 1.50 \\
Ig levels at 1 day of age & $\mathrm{mg} / \mathrm{ml}$ & 30.58 & 86.85 & 69.37 & 12.19 \\
Ig levels at 7 days of age & $\mathrm{mg} / \mathrm{ml}$ & 27.66 & 76.18 & 62.83 & 12.07 \\
Body weight at 7 days of age & $\mathrm{kg}$ & 38.00 & 58.00 & 45.85 & 5.52 \\
Body weight at 30 days of age & $\mathrm{kg}$ & 39.00 & 63.00 & 51 & 5.62 \\
Daily body weight gain at 30 days of age & $\mathrm{kg}$ & 0.20 & 0.50 & 0.13 & 0.13 \\
\hline
\end{tabular}


Table 2. The comparison of groups according to weight and colostrum measurements

\begin{tabular}{lccccc}
\hline Variables & Groups & Mean & Standard deviation & Standard error & P value \\
\hline \multirow{3}{*}{ Birth weight } & Group 1 & 45.83 & 5.49 & 2.24 & \\
& Group 2 & 44.40 & 5.13 & 1.62 & 0.27 \\
& Group 3 & 41.64 & 5.52 & 1.66 & \\
Colostrum & Group 1 & 74.21 & 9.29 & 3.79 & \\
& Group 2 & 59.79 & 16.51 & 5.22 & 0.10 \\
& Group 3 & 63.63 & 9.92 & 2.99 & \\
Blood sample on birth day & Group 1 & 3.24 & 2.88 & 1.18 & \\
& Group 2 & 2.17 & 0.90 & 0.28 & 0.17 \\
& Group 3 & 1.80 & 0.43 & 0.13 & \\
Blood sample on day 1 & Group 1 & 65.92 & 18.80 & 7.67 & \\
& Group 2 & 70.62 & 11.35 & 3.59 & 0.75 \\
& Group 3 & 70.11 & 9.18 & 2.77 & \\
Blood sample on day 7 & Group 1 & 60.72 & 16.40 & 6.70 & \\
& Group 2 & 58.78 & 13.32 & 4.21 & 0.22 \\
& Group 3 & 67.67 & 6.30 & 1.90 & \\
Weight on day 7 & Group 1 & 48.50 & 4.68 & 1.91 & \\
& Group 2 & 46.10 & 5.32 & 1.68 & 0.31 \\
\hline \multirow{3}{*}{ Weight on day 30 } & Group 3 & 44.18 & 5.96 & 1.80 & \\
\hline \multirow{3}{*}{ Daily body weight gain } & Group 1 & 54.00 & 5.29 & 2.16 & \\
& Group 2 & 50.30 & 4.55 & 1.44 & 0.34 \\
& Group 3 & 50.00 & 6.53 & 1.97 & \\
\hline
\end{tabular}

Table 3. Correlation of colostrum IgG levels between refractometer and ELISA analyses

\begin{tabular}{lccc}
\hline Variables & & Refractometer & Colostrum lgG level \\
\hline \multirow{3}{*}{ Refractometer } & Pearson Correlation & 1 & 0.195 \\
& P & & 0.329 \\
& N & 27 & 27 \\
\hline \multirow{3}{*}{ Colostrum lgG level } & Pearson Correlation & 0.195 & 1 \\
& P & 0.329 & \\
& N & 27 & 27 \\
\hline
\end{tabular}

\section{DISCUSSION}

Calves are born hypogammaglobulinemic due to considerably low amount of immunoglobulins that are transferred from the placenta in ruminants. For this reason, calves must consume colostrum within the first 2 hours after birth to transfer the maternal passive antibodies and build the calf's immune system. Passive transfer failure occurs in calves that have not consumed adequate amount of colostrum, and calves become resistant to diseases (S.entürk 2012). According to Weaver et al. (2000), the calf should not be allowed to suckle immediately after birth. High rates of passive transfer failure reportedly occur in calves that are allowed to suckle their mother. Here, we did not observe passive transfer insufficiency for approximately $30 \mathrm{~min}$ after the calves were cleaned and dried. Considering the results of our study, we could not observe passive transfer failure in calves in Group 1 possibly due to the fact that the calf may have been resting, getting over birth stress, and recovering metabolically for $30 \mathrm{~min}$ after birth, and thus getting enough colostrum. However, despite the lack of inter-group statistical differences, the lowest $\operatorname{IgG}$ level was determined in Group 1. Therefore, it may be possible to acquire more precise results by increasing the number of animals used in the study. 
Besser et al. (1991) investigated three different methods of administering colostrum in Holstein calves, which included feeding the colostrum with a probe, feeding colostrum with bottles, and directly sucking it from the mother were compared, and passive transfer failure rates were revealed. Consequently, the passive transfer failure was found in $10.8 \%$ of those fed by the probe, $19.3 \%$ of those who were fed a bottle, and $61.4 \%$ of those who suckled their mothers. According to our study, passive transfer failure (less than $10 \mathrm{mg} / \mathrm{mL}$ of serum immunoglobulin density) was not observed between the groups.

Laestander (2016) compared the methods to administer colostrum, which includes feeding with a bottle, probe, and suckling the mother. In this study, the calves were monitored for 2 weeks, and their feed intake, growth rate, and health status were recorded. In addition, IgG concentrations were measured in the colostrum of the mothers and in the calf blood at the $24^{\text {th }}$ and $48^{\text {th }}$ hour after birth through ELISA. The results revealed no significant difference between the different feeding methods in terms of serum $\operatorname{IgG}$ levels at the $24^{\text {th }} \mathrm{h}$ and $48^{\text {th }} \mathrm{h}$ or calf health. Similarly, we found no significant inter-group differences in terms of $\lg G$ level in blood serum taken $24 \mathrm{~h}$ after delivery $(\mathrm{P}>0.05)$. According to the results of the research conducted by Besser et al. (1991), the passive transfer failure rates were found to be $61 \%, 19 \%$, and $64 \%$ and $15 \%$ in calves that suckled their mother, bottle, and administering 21 with a catheter and $4 \mathrm{~L}$ with a catheter, respectively. According to our study, no significant inter-group differences were observed in terms of passive transfer failure ( $\mathrm{P}>0.05$ ). Recording the daily body weight increases revealed a minor inter-group difference specifically in the calves in Group 2. Calves in the Groups 1 and 3 presented with an identical increase in the daily live weight (mean=0.27 for group 1 and 0.28 for group 3), while Group 2 calves had lower daily live weight increase (Mean=19). However, this numerical difference was not statistically significant $(\mathrm{P}>0.05)$.

A Brix refractometer is an instrument developed to measure the amount of $\operatorname{IgG}$ in the colostrum. The scale (measure) in the Brix refractometer was designed to measure the amount of sucrose in a solution; however, the Brix values could be associated with the Ig in the colostrum. There is a reportedly 0.63 correlation between laboratory analysis results obtained for IgG using radial immunodiffusion and Brix refractometer values. A Brix value of $22 \%$ in the scale corresponds to $50 \mathrm{mg} / \mathrm{mL}$, that the colostrum measured is of a high quality. The colostrometer measures the specific gravity of the colostrum and evaluates the total gamma globulin level based on a statistical relationship. It is widely used to determine IgG concentrations in colostrum (Quigly 2009). According to Deelen et al. (2014), a refractometer control can be used to detect a digital Brix refractometer in detecting maternal immunoglobulin compared to measuring serum total protein. The percentage of Brix demonstrated significant correlations with the $\operatorname{IgG}$ levels. No significant relationship was found between refractometer results and serum immunoglobulin results $(\mathrm{P}>0.05)$. Accordingly, using a refractometer to estimate the colostrum immunoglobulin level may cause inaccurate evaluation.

Despite the absence of statistically significant intergroup differences, the blood IgG levels of the 1st group calves were thought to be numerically lower than the other groups, along with the presence of a significant difference that could be observed with increase in the number of animals. While our study presented different results with the study of Besser et al. (1991), our study yielded results consistent with those of Laestander (2016) and Weaver et al. (2000).

Therefore, calf colostrum should be obtained immediately after birth, while maintaining a certain degree of hygiene. The method or amount can be selected according to the infrastructure and capability of the farm. Checking the $\mathrm{lg}$ level with a refractometer may give misleading results. Therefore, accuracy can be ensured by using the ELISA method. It is not surprising that this method is not practical and suitable for use in field conditions. Thus, from the perspective of the results obtained from our research, it was concluded that the calf losses due to colostrum insufficiency can be minimized by producing refractometers suitable for practical use or ready-made diagnostic kits that provide results as reliable as ELISA results.

\section{ACKNOWLEDGEMENT}

This study is summarized from the Master's thesis of the first author.

This study was supported by Afyon Kocatepe University Scientific Research Projects Coordination Unit. (Project No: 18.KARIYER. 252).

The study was approved by the Afyon Kocatepe University Local Animal Ethical Committee (26.06.2018/108-18).

Conflict of Interest: The authors declare that they have no conflict of interest.

\section{REFERENCES}

Besser TE, Gay CC, Pritchett L. Comparison of three methods of feeding colostrum to dairy calves. J Am Vet Med Assoc. 1991;198(3):419-22.

Deelen SM, Ollivett TL, Haines DM, Leslie KE. Evaluation of a Brix refractometer to estimate serum immunoglobulin $G$ concentration in neonatal dairy 
calves. J Dairy Sci. 2014; 97:3838-3844. DOI: 10.3168/jds.2014-7939

Hamilton T, Giesen L. Effect of colostrum quality and management on immunity transfer of beef calves. http://131.104.112.18/beefupdate /Article94/a-effectof-colostrum-quality-and-htm. 2003.

Hurley WL, McCoy G. Supplementing low and medium quality colostrum with dried serum. http://traill.outreach.uiuc.edu/. 2003.

Korhonen H, Marnila P, Gill HS. Milk immunoglobulins and complement factors. Br J Nutr. 2000; 84(S1):75-80. DOI: $10.1017 /$ S0007114500002282.

Laestander C. Comparison of three different colostrum feeding methods on passive transfer of immunity, growth and health in dairy calves. PhD Thesis, Swedish University of Agricultural Sciences, Uppsala, 2016.

Morter RL. Feeding colostrum to calves. Cooperative Extension Service Purdue University West Lafayette, IN 47907, Indiana, 2003.

Özen N. Süt Sığırlarının Beslenmesi. Akd. Üniv. Ziraat Fak. Yayınları. Yardımcı Ders Notu No:3. Antalya, 1999.

Quigley JD, Drewry JJ. Nutrient and immunity transfer from cow to calf pre- and postcalving. J Diary Sci. 1998; 81(10):2779-2790

Quigley JD. Using the colostrometer to measure colostrum quality. http://www.calfnotes.com/pdffiles /CN022.pdf 2001. Accession date: 15.10.2009.

Selk GE. Management factors that affect the development of passive immunity in the newborn calf. http://www.iowabeefcenter.org/bch/PassiveImmunityM gt.pdf. Accession date: 21 Temmuz 2014.

Şentürk S. Olgu Tartışmalı Buzağılların İç Hastalıkları, F. Özsan Matbaacilık, Bursa, 2012.

Wattiaux MA. Heifer Raising Birth to Weaning 28 Importance Of Colostrum Feeding. http://Babcock.Cals. Wisc. Edu/Downloads/De/28.En.Pdf. 2014.

Waterman D. Colostrum. http://www. moormans.com/feedfacts/dairy/dairymar98/ colostru.html. 1998.

Weaver DM, Tyler JW, VanMetre DC, Hostetler D, Barrington GM. Passive transfer of colostral immunoglobulin in calves. J Vet Intern Med. 2000;14:569-577. 1676.2000.tb02278.x 